\title{
Sekolah Alam: Paradigma Baru Pendidikan Islam Humanis
}

\author{
Rohinah \\ UIN Sunan Kalijaga Yogyakarta \\ Email: rohinah80@yahoo.com
}

\begin{abstract}
This paper describes a new paradigm of Islamic education in the perspective of humanism based on nature school model. This school model has three specific aspects, namely: natural as learning space, nature as media and teaching materials, and natural as learning objects. It is a creativity in building a humanist paradigm of Islamic education. The education system emphasizes awareness to encourage the process of dialogue between teachers and students. Dialogical process can bring an attitude of humility and affection that is open to criticism from the learners. Learners are required critical and questioned again about the unknown by the teacher. This kind of learning led to a harmonious communication between all parties. School of Natural allow the emergence of awareness. This school gives the freedom to create, explore and discover potential, and find the knowledge based on experiences from the world of reality.
\end{abstract}

Keywords: Islamic education, school of nature, self-realization

\begin{abstract}
Abstrak
Makalah ini menjelaskan paradigma baru pendidikan Islam dalam perspektif humanisme dengan bertolak pada model sekolah alam. Model sekolah ini memiliki tiga aspek khusus, yakni: alam sebagai ruang belajar, alam sebagai media dan bahan mengajar, serta alam sebagai objek pembelajaran. Pendidikan seperti ini merupakan sebuah kreativitas dalam membangun paradigma pendidikan Islam yang humanis. Sistem pendidikan ini menekankan penyadaran untuk mendorong adanya proses dialog antara guru dan anak didik. Proses dialogis dapat memunculkan sikap rendah hati dan kasih sayang sehingga terbuka terhadap kritik dari peserta didik. Peserta didik dituntut kritis dan mempertanyakan kembali tentang hal yang belum diketahui oleh sang guru. Pembelajaran semacam ini memunculkan kesadaran siswa dan komunikasi yang harmonis antara semua pihak. Sekolah ini memberikan kebebasan untuk berkreasi, menggali dan menemukan potensi, serta menemukan pengetahuan berbasis pada pengalaman-pengalaman dari dunia realitas.
\end{abstract}

Kata kunci: pendidikan Islam, sekolah alam, penyadaran diri 


\section{A. Pendahuluan}

Pendidikan Islam sampai saat ini sepertinya belum memainkan peran strategisnya dalam menciptakan pribadi-pribadi muslim yang unggul dan berkepribadian baik. Hal ini disebabkan masih banyaknya praktek di lembaga-lembaga pendidikan Islam yang masih memberikan dominasi pada aspek kognitif dan penekanan pada aspek hafalan dalam memahami pendidikan keagamaan. Kepribadian dan akhlak anak didik hanya berhenti pada nilai angka-angka nominal semata, keberhasilan pendidikan agama diukur manakala anak memperoleh angka di atas KKM, kepintaran anak dinilai manakala mampu menghafal materi-materi agama yang sudah ditentukan berdasarkan bahan ajar yang ada dan batasan-batasan yang sudah dipersiapkan secara terukur dan terstruktur menurut aturan yang sangat sempit dan sangat minim terjadinya ruang dialog secara interaktif antar guru dan peserta didik. Anak hanya terjebak pada batasan salah dan benar, baik dan buruk, surga dan neraka, serta pahala dan siksa. Sehingga sangat sempit ruang bagi anak untuk bisa berpikir kreatif dan kritis, karena jawaban-jawaban anak didik ditentukan oleh benar dan salah yang ditentukan dalam buku-buku teks ajar semata.

Menurut Munir Mulkhan, sesungguhnya persoalan moral yang sedang dialami bangsa ini dimulai dari ruang kelas yang cacat moral dan memasung daya kritis dan kreativitas. Anak-anak hanya dipandang sebagai sosok yang hanya berharga jika sesuai citra guru, pengelola pendidikan, dan pemerintah. Anak-anak tidak pernah diajak untuk mengerti, mengalami, dan menyadari kebaikan dan kebenaran saat semuanya tersedia oleh paket-paket pembelajaran. Tuhan pun tak pernah dikenal dan disadari, kecuali sifat-sifat hebatNya yang harus dihafal tanpa bertanya. Penindasan kehendak adalah pengalaman paling jelas dan otentik sejak anakanak manusia memasuki bangku sekolah. ${ }^{1}$

Maraknya kehadiran sekolah alam saat ini seakan-akan memberikan angin segar dalam dunia pendidikan. Banyak kalangan yang menyambut hangat kehadiran sekolah yang berbasis alam sebagai bentuk kekecewaan dan keputusasaan atas harapan besar yang selama ini belum dipenuhi lembaga pendidikan konvensional. Sekolah alam dianggap menjadi

1 Abdul Munir Mulkhan, Nalar Spiritual Pendidikan, (Yogyakarta: Tiara Wacana, 2002), hlm. 74-75. 
alternatif baru dalam dunia pendidikan yang selama ini tengah mengalami kebosanan dan stagnasi keilmuan. Termasuk dalam dunia pendidikan Islam yang perlu pengalaman nyata, dan bentuk kesadaran diri melalui pengalaman keberagamaan yang nyata. Sekolah alam dekat dengan alam, sebagai bentuk tadabbur alam dan dekat dengan pengalaman nyata dalam kehidupan anak didik. Sehingga pendidikan Islam harus berubah ke arah pengalaman dan penyadaran diri tersebut. Berangkat dari persoalan tersebut di atas, maka makalah ini akan memfokuskan pada kajian pendidikan Islam berbasis sekolah alam sebagai bentuk perubahan ke arah paradigma baru pendidikan yang lebih humanis dan kreatif.

\section{B. Sekolah Alam: Model Perubahan Pendidikan Islam Humanis}

Pendidikan Islam sepertinya belum sepenuhnya mengakomodir kepentingan untuk menempatkan anak didik pada keunikan masing-masing. Hal ini ditunjukkan dengan masih adanya sentralisasi kebijakan dan strategi pendidikan yang menegasikan keunikan personal anak manusia. Sehingga yang terjadi dalam pendidikan Islam hanya sekedar mentransfer pengetahuan semata dan pada akhirnya menimbulkan terjadinya dehumanisasi dalam dunia pendidikan. ${ }^{2}$

Keberadaan Sekolah Alam yang saat ini mulai marak di lingkungan kita sepertinya menjadi alternatif baru dalam dunia pendidikan yang sedang mengalami kejenuhan dan stagnasi. Bagi kalangan yang kritis terhadap dunia pendidikan menyadari betapa pentingnya menghadirkan sekolah berwajah humanis yang selama ini belum terakomodir dalam sekolah formal pada umumnya. Maka, kehadiran sekolah alam ini dapat menjadi angin segar untuk menghidupkan kembali nilai-nilai kemanusiaan dalam dunia pendidikan.

\footnotetext{
${ }^{2}$ Dehumanisasi menjadi lawan kata humanisasi. Dalam kacamata Freire Humanisasi dan dehumanisasi adalah dua hal yang bersifat antagonistik. Dehumanisasi dalam pendidikan dimaksudkan sebagai proses pendidikan yang terbatas pada pemindahan ilmu pengetahuan (transfer of knowledge). Sedangkan humanisasi merupakan proses pemberdayaan masyarakat melalui ilmu pengetahuan. Lihat Paulo Freire, Politik Pendidikan: Kebudayaan, Kekuasaan dan Pembebasan, terj. Agung Prihantoro dan Fuad Arif Fudiyartanto, (Yogyakarta: Pustaka Pelajar \& READ, 2002), hlm. 190-191. Bandingkan pula dengan Said Tuhuleley (ed). Masa Depan Kemanusiaan, (Yogyakarta: Jendela, 2003), hlm. 7.
} 
Sekolah alam adalah bentuk pendidikan alternatif yang menggunakan alam sebagai media utama pembelajaran murid. Di sini, anak belajar dari semua makhluk yang ada di alam semesta. Dalam konsep pendidikan sekolah alam, terdapat 3 fungsi, yakni: alam sebagai ruang belajar, alam sebagai media dan bahan mengajar, alam sebagai objek pembelajaran.

Adapun ciri khas dari sekolah alam di antaranya; anak didik lebih banyak belajar di alam terbuka, metode belajar mengajar lebih banyak menggunakan metode action learning, yaitu anak didik belajar melalui pengalaman. Jika mengalaminya secara langsung, ia akan belajar lebih bersemangat, tidak bosan, dan lebih aktif, dan yang terpenting lagi penggunaan alam sebagai media belajar bertujuan agar murid lebih peduli dengan lingkungan dan bisa menerapkan pengetahuan yang dipelajari. ${ }^{3}$

Kehadiran sekolah alam ibarat sebuah impian yang menjadi kenyataan bagi mereka yang mengangankan dan menginginkan perubahan dalam dunia pendidikan. Bukan sekedar perubahan sistem, metode dan target pembelajaran, melainkan perubahan paradigma pendidikan secara menyeluruh yang pada akhirnya mengarah pada perbaikan mutu dan hasil dari proses pendidikan itu sendiri.

Di sekolah alam, anak didik dibebaskan bereksplorasi, bereksperimen dan berekspresi tanpa dibatasi sekat-sekat dinding yang mengekang rasa ingin tahu mereka yang membatasi interaksi mereka dengan kehidupan yang sebenarnya yang membuat mereka berjarak dan tidak akrab dengan alam lingkungan mereka.

Kehadiran sekolah alam ibarat sebuah impian yang menjadi kenyataan bagi mereka yang mengangankan dan menginginkan perubahan dalam dunia pendidikan. Bukan sekedar perubahan sistem, metode dan target pembelajaran, melainkan perubahan paradigma pendidikan secara menyeluruh yang pada akhirnya mengarah pada perbaikan mutu dan hasil dari proses pendidikan itu sendiri.

Di sekolah alam, anak didik dibebaskan bereksplorasi, bereksperimen dan berekspresi tanpa dibatasi sekat-sekat dinding yang mengekang rasa ingin tahu mereka yang membatasi interaksi

${ }^{3}$ www/Sekolah Alam/Keuntungan Anak Belajar di Sekolah Alam Usia Sekolah Parenting.co.id.htm. Diakses 7 Desember 2014. 
mereka dengan kehidupan yang sebenarnya yang membuat mereka berjarak dan tidak akrab dengan alam lingkungan mereka.

Anak didik dibebaskan menjadi diri mereka, dan mengembangkan potensi diri untuk tumbuh menjadi manusia yang berkarakter, berakhlak mulia, berwawasan ilmu pengetahuan dan siap menjadi pemimpin sesuai hakikat menciptakan manusia untuk menjadi pemimpin di muka bumi (khalifah fi al-ard). Anak didik juga dibebaskan dari tekanan 'mengejar' nilai dan ranking, tapi didorong untuk menumbuhkan tradisi ilmiah. Prestasi tidak dilihat dalam perbandingan dengan anak lain, tapi dari upaya mereka mengikuti proses belajar dengan baik. Belajar menjadi sesuatu yang menyenangkan. Bahkan belajar menjadi sebuah kebutuhan yang datang dari dalam diri anak didik dan bukan menjadi sebuah keterpaksaan. Dan yang terpenting lagi bagi anak didik adalah sekolah tidak menjadi penjara yang membosankan.

Sistem pendidikan di sekolah alam sesungguhnya lebih dapat mengakomodir keunikan masing-masing personal untuk dapat dikembangkan sesuai dengan minat dan potensinya. Sehingga bukan lagi penyeragaman yang diharapkan melainkan ketidakseragaman dan keunikan.

Karena sesungguhnya menurut Munir Mulkhan, pendidikan seharusnya menjadi wahana manusia untuk belajar menyelesaikan problem kehidupan yang sedang dan akan dihadapi. Namun sayangnya, pendidikan lebih sebagai sebuah paket peniruan gaya hidup versi penguasa, birokrat pendidikan dan para orang dewasa. Sehingga yang terjadi pendidikan sering terperangkap sebagai praktik kekunoan dan gaya hidup generasi terdahulu yang ketinggalan zaman. ${ }^{4}$

Humanisme dalam pendidikan menurut Darmiyati Zuchdi adalah bentuk pendidikan yang mempertimbangkan konsepsi moralitas. Konsepsi itu meliputi kepatuhan pada hukum moral, konformitas pada aturan-aturan sosial, otonomi rasional dalam hubungan antar pribadi, dan otonomi eksistensial dalam pilihan seseorang. Keempat konsepsi itu sebagai dasar pertimbangan capaian peserta didik dalam membentuk sifat-sifat human. ${ }^{5}$

\footnotetext{
${ }^{4}$ Abdul Munir Mulkhan, Nalar Spiritual..., hlm. 163-164.

5 Darmiyati Zuchdi, Humanisasi Pendidikan, (Jakarta: Bumi Aksara,
} 2008), hlm. 2. 
Dengan demikian, pendidikan Islam berbasis sekolah alam sesungguhnya mampu menjadi terobosan baru mencari format pendidikan Islam yang lebih humanis. Dengan pendidikan Islam berbasis sekolah alam diharapkan akan terjadi perubahan dalam semua dimensi pendidikan yang selama ini justru melanggengkan dehumanisasi.

\section{Mencari Arah Perubahan: Pendidikan Agama melalui Penyadaran Diri}

Pendidikan Agama sering terjebak pada persoalan hafalan semata, baik itu menghafal ayat-ayat al-Qur'an maupun teks-teks hadis nabi. Namun sesungguhnya yang terpenting dalam mengajarkan agama adalah bagaimana menjadikan nilai-nilai yang terkandung dalam ayat-ayat suci maupun hadis nabi tersebut memiliki kebermaknaan yang nyata dalam kehidupan anak didik. Sebagaimana menurut Kareel A. Steenbrink, bahwa memahami agama sesungguhnya tidak hanya meliputi hubungan antara manusia dengan Tuhan, melainkan juga antara manusia dengan manusia, dunia dan masyarakat, sejauh yang diatur dengan wahyu yang diturunkan Allah. ${ }^{6}$

Dari sini, maka sudah jelas sekali jika keberadaan pendidikan agama bukan berarti mengajarkan anak didik terkungkung oleh nilai-nilai normativitas keagamaan hanya untuk meningkatkan kesalehan personal semata, melainkan bagaimana pendidikan agama bisa membawa seorang anak didik pada kesalehan personal dan juga sosial.

Bila kita kembali berkiblat pada tujuan pendidikan nasional sebagaimana tercantum dalam UU Nomor 20 Tahun 2003 tentang Sistem Pendidikan Nasional adalah membentuk manusia yang berbudi pekerti luhur melalui proses pembentukan kepribadian, kemandirian dan norma-norma tentang baik dan buruk. Pendidikan diartikan sebagai suatu proses penyiapan generasi muda untuk menjalankan kehidupan dan memenuhi tujuan hidupnya secara lebih efektif dan efisien. Dan dalam pasal 1 UU Sistem Pendidikan Nasional juga jelas memposisikan bahwa pendidikan adalah usaha sadar dan terencana untuk mewujudkan suasana belajar dan proses pembelajaran agar peserta didik secara aktif mengembangkan

6 Kareel A. Steenbrink, Pesantren, Madrasah, Sekolah, (Jakarta: LP3ES, 1986), hlm. 107. 
potensi dirinya untuk memiliki kekuatan spiritual keagamaan, pengendalian diri, kepribadian, kecerdasan, akhlak serta keterampilan yang di perlukan dirinya, masyarakat, bangsa dan negara. $^{7}$

Dari penjelasan di atas sesungguhnya telah sangat jelas digambarkan bahwa pendidikan sebagai usaha sadar untuk mengaktualisasikan setiap potensi fitrah yang ada pada setiap manusia. Dan potensi tersebut harus dikembangkan untuk mengantarkan setiap individu pada proses pendewasaan sosial untuk mencapai perkembangan manusia seutuhnya. Dan di antara potensi fitrah manusia yang bisa dikembangkan adalah modal dasar manusia sebagai makhluk yang berpikir dan mempunyai kesadaran. Potensi tersebut dapat berkembang dengan baik manakala proses pendidikan yang diberikan menitikberatkan pada pada eksistensi manusia itu sendiri. Sementara proses pendidikan yang mendukung untuk terciptanya eksistensi manusia tentu mengarah kepada mekanisme yang demokratis dan senantiasa berorientasi pada proses memanusiakan manusia. Dengan begitu proses pendidikan bukan hanya semata-mata menjadi agen transfer ilmu pengetahuan, namun lebih mengarahkan dan membantu anak didik untuk bisa memaksimalkan potensinya dalam rangka menggali pengetahuan yang luas, kritis, dan komprehensif.

Paulo Freire seorang tokoh pendidikan Kritis asal Brazil yang memiliki pandangan yang lebih menekankan peserta didik sebagai subjek yang bebas ketimbang objek yang hanya menerima pengetahuan dari manusia yang dianggap lebih tahu kepada manusia yang dianggap belum tahu. Pendidikan kontekstual atau hadap masalah adalah sebuah teori dan model pendidikan yang mengupayakan peserta didik untuk menjadi subyek dalam rangka menjawab persoalan-persoalan yang muncul dalam realitas sosial. Freire menekankan peran berpikir dalam pembuatan kembali dunia. Dari sini fakta sosial bisa diungkapkan melalui pendidikan, dan menurut Freire, harus diupayakan adanya penyatuan (integration) dunia fakta (nyata) ke dalam dunia pendidikan. ${ }^{8}$

${ }^{7}$ Moh. Yamin, Menggugat Pendidikan Indonesia Belajar dari Paulo Freire dan Ki Hajar Dewantara, (Jogjakarta: Ar-Ruzz Media, 2009), hlm. 19.

8 Moh. Yamin, Menggugat Pendidikan ..., hlm. 19. Lihat pula http/elemen-elemen kritis dalam konsep pendidikan paulo freire.htm. Diakses 7 Desember 2014. 
Istilah penting yang diajukan Freire dalam Pedagogy of The Oppressed untuk mengajukan teorinya adalah penyadaran (conscientizacao) atau yang sering kita sebut "konsientisasi". Konsientisasi adalah pemahaman mengenai keadaan nyata yang sedang dialami siswa atau murid. Meskipun wilayah terakhir yang ingin dituju adalah perubahan sistemik, namun pendidikan Freire bertujuan untuk pembebasan dan pemanusiaan (humanisasi). Dalam rangka itulah Freire melihat bahwa 'penyadaran' (konsientisasi) sebagai inti dari pendidikannya. Pendidikan harus bertujuan menyadarkan peserta didik akan realitas sosialnya.

Freire (1979) membagi kesadaran manusia menjadi kesadaran magis, naif, dan kritis. Pertama, kesadaran magis (magical consciousness) adalah kesadaran masyarakat yang tidak mampu melihat kaitan antara satu faktor dengan faktor lain. Misalnya masyarakat miskin yang tidak mampu melihat kaitan antara kemiskinan mereka dengan sistem politik dan kebudayaan. Kesadaran ini lebih melihat pada faktor di luar manusia (natural maupun supranatural) sebagai penyebab dari ketidakberdayaannya.

Kedua, kesadaran naif (naival consciousness) yang lebih melihat aspek manusia menjadi akar permasalahan dalam masyarakat. Dalam kesadaran ini, masalah etika, kreativitas, need for achievement dianggap sebagai penentu perubahan sosial. Jadi dalam menganalisis mengapa suatu masyarakat miskin, mereka menganggap hal itu karena salah mereka sendiri.

Ketiga, kesadaran kritis (critical consciousness) yang lebih melihat pada aspek sistem dan struktur sebagai sumber masalah. Pendidikan mencoba menganalisis secara kritis sistem dan struktur sosial, politik, ekonomi, budaya, dan konteks masyarakat lainnya. Paradigma kritis dalam pendidikan adalah melatih siswa agar mampu mengidentifikasi ketidakadilan dalam sistem dan struktur yang ada, kemudian menganalisis bagaimana sistem itu bekerja, serta bagaimana mentransformasikannya. Tugas pendidikan dalam paradigma ini adalah menciptakan ruang dan kesempatan agar siswa terlibat aktif dalam proses penciptaan struktur yang secara fundamental baru dan lebih baik. ${ }^{9}$

${ }^{9}$ William A. Smith, Conscientizacou Tujuan Pendidikan Paulo Freire, terj. Agung Prihantoro, (Yogyakarta: Pustaka Pelajar, 2001). 
Hal positif yang dapat dipetik dari teori pendidikan kritis Freire mengenai penyadaran (konsientisasi) adalah bahwa pendidikan harus mendorong adanya proses dialogis antara guru (pengajar) dan anak didik. Maka dengan paradigma dialogis ini seorang pengajar harus rendah hati dan mengasihi peserta didiknya supaya terbuka terhadap berbagai kritik dari peserta didik. Sebaliknya, peserta didik seharusnya senantiasa kritis dan mempertanyakan kembali tentang hal yang belum diketahui oleh sang guru. Dari sini, akan terjadi komunikasi dua arah yang harmonis dan proses pembelajaran tidak hierarkis atas - bawah, pintar - bodoh, sudah tahu - belum tahu dan seterusnya.

Sementara Munir Mulkhan memformulasikan adanya integrasi kepribadian pada anak didik. Integrasi kepribadian ialah pribadi setiap individu yang terintegrasi pada setiap pertumbuhan dan perkembangan dirinya. Individu anak didik ini benar-benar menyadari bahwa hidupnya adalah sebuah "proses menjadi", "proses berubah" dan "proses berkembang". Di dalam proses situ seorang anak didik terus berusaha secara sadar memilih berbagai pengalaman yang kondusif atau mendukung perkembangan, perubahan dan pertumbuhannya tersebut. Karena pilihannya dan kesadarannya itulah anak didik dengan suka rela menerima risiko, menghadapi konflik dan pertentangan dengan keinginannya. ${ }^{10}$

Dalam proses pembelajaran agama sangat dibutuhkan nuansa dialogis-harmonis. Karena persoalan pembelajaran agama tidak semata bersifat indoktrinasi nilai-nilai yang dianggap sudah mapan dan tidak perlu dikritisi dan diinterpretasi kembali. Akan tetapi pembelajaran agama sesungguhnya sangat dinamis dan progresif, sehingga sangat terbuka akan adanya perkembanganperkembangan pengetahuan seiring dengan laju perkembangan zaman. Maka, pendidikan Islam perlu mengevaluasi kembali bagaimana proses pembelajaran agama yang selama ini diterapkan di sekolah-sekolah apakah sudah menuju pada humanisasi pendidikan ataukah masih terkungkung pada struktur kemapanan?

Di sekolah alam yang berbasis pada pendekatan pembebasan sangat dimungkinkan adanya ruang untuk mengarah pada pendidikan melalui penyadaran sebagaimana teori yang dikemukakan Freire tersebut. Karena dalam proses pembelajaran di sekolah alam anak didik sangat diberikan kebebasan untuk

${ }^{10}$ Abdul Munir Mulkhan, Nalar Spiritual..., hlm. 93. 
berkreasi, menggali dan menemukan potensi, serta menemukan pengetahuan berbasis pada pengalaman-pengalaman dari dunia realitas. Oleh karena itu, hal ini merupakan terobosan baru dalam dunia pendidikan yang patut diapresiasi dan alternatif lain dari pendidikan yang sudah mapan untuk menemukan eksistensi manusia seutuhnya.

\section{Peran Guru Sebagai Perantara Antara Manusia dan Tuhan}

Selama ini dalam mengajarkan agama guru cenderung menerapkan sikap hitam putih, baik - buruk, benar salah, surga neraka, serta pahala - dosa. Pola pengajaran agama yang selama ini diterapkan guru cenderung menutup ruang bagi anak didik untuk berpikir kritis, dan kreatif. Anak hanya disuguhi bahan-bahan yang siap jadi tanpa ada kompromi, dan harus ditelan secara mentah bahwa itulah ajaran agama yang tidak boleh ditentang adanya, apalagi diingkarinya. Yang terjadi anak didik membayangkan sesuatu yang menakutkan terlebih dahulu sebelum melaksanakan ajaran-ajaran tersebut. Bayangan dosa dan neraka telah menghantui dalam alam pikir dan perasaan anak didik. Dan yang terjadi adalah anak didik mendapatkan pengajaran agama bukan berdasarkan kesadaran dirinya melainkan karena ada unsur keterpaksaan untuk melaksanakan kewajiban semata.

Menurut Abdurrahman Mas'ud, konsep pendidikan Islam humanis seorang guru harus berperan sebagai orang yang mempersiapkan anak didik dengan kasih sayangnya sebagai individu yang saleh dalam arti memiliki tanggung jawab sosial, religius dan lingkungan hidup. Guru tidak hanya sekedar melakukan transfer of knowledge atau transfer of value saja tetapi lebih dari itu. Seorang guru harus bisa mengembangkan individu dalam rangka menerapkan dan meraih tanggung jawab. Ucapan, tata bersikap, dan tingkah laku seorang guru ditujukan agar siswa bisa menjadi insān kamil. ${ }^{11}$ Guru bukanlah orang yang serba dan paling mengerti dunia anak didiknya. Guru merupakan seseorang yang mampu mendorong siswa menyadari diri dan kemampuannya sendiri. ${ }^{12}$

${ }^{11}$ Abdurrahman Mas'ud, Menggagas Format Pendidikan Nondikotomik Humanisme Religius sebagai Paradigma Pendidikan Islam, (Yogyakarta: Gama Media, 2002), hlm. 196-197.

12 Abdul Munir Mulkhan, Nalar Spiritual..., hlm. 90. 
Untuk mewujudkan pendidikan Islam yang humanis harus dimulai dari guru yang humanis pula. Seorang guru yang humanis sangat menghindarkan adanya penekanan pada siswa. Seorang peserta didik diterima apa adanya, dengan kelebihan dan kekurangannya sehingga tidak ada yang merasa tertekan, baik pihak siswa maupun guru, psikis maupun fisiknya. Seorang guru humanis tidak pernah menginginkan anak didiknya hanya sekedar menjadi peniru dari model yang ditampilkan gurunya. Implikasi aliran humanisme dalam pendidikan adalah keniscayaan pengembangan potensi diri manusia sebagai anak didik. ${ }^{13}$

Di sekolah alam, guru harus mampu berkreasi dalam mengajar. Dan kreativitas guru tidak dibatasi oleh buku paket dan target nilai. Guru tidak hanya sekedar mengajar, tapi mendidik. Guru tidak hanya menjadi panutan, melainkan juga menjadi teman serta pendengar yang baik. Guru dalam hal ini lebih memainkan perannya sebagai seorang fasilitator ketimbang seorang tutor. Guru-guru memiliki idealisme tinggi dan berdedikasi di sekolah untuk membantu anak didik mengenali kelebihan dan kekurangannya serta menjadikan mereka merasa dihargai. Guru tidak sekedar kenal tapi paham; tidak sekedar berilmu tapi berkarakter dan berakhlak mulia; tidak sekedar mandiri tapi bisa membedakan mana yang baik dan yang tidak baik dikerjakan.

\section{E. Tadabbur Alam: Menggeser Pembelajaran Agama dari Paradigma Mitis ke Fungsional}

Proses pembelajaran di sekolah alam sudah seharusnya menjadikan alam sebagai sumber belajar, sarana, metode, bahkan strategi pembelajaran. Lingkungan anak yang dekat dengan alam sesungguhnya sangat strategis untuk mengajarkan agama berbasis lingkungan alam sekitar. Alam merupakan lingkungan yang paling dekat dan paling realistis bagi dunia anak. Sesungguhnya dalam proses pendidikan pun sangat diharapkan untuk mendekatkan anak didik pada alam nyata. Sehingga antara alam ide yang ada dalam teori-teori yang diajarkan di kelas sesungguhnya bisa berbanding lurus dengan apa yang ada di alam nyata. Sehingga benar apa yang dikatakan Paulo Freire bahwa tidak boleh ada dikotomi di antara

${ }^{13}$ Nur Chayati, "Menelusuri Akar Bungkamnya Daya Kritis", Edukasi, Vol. II, No.1, Januari, 2004, Fakultas Tarbiyah IAIN Walisongo Semarang, hlm. 60 . 
tujuan pendidikan dan cara pendidikan. Tujuan (transformasi yang membebaskan setiap orang agar menjadi manusia sejati), seharusnya terwujud dalam bagaimana pendidikan dilaksanakan. Tujuan pembebasan tidak tidak terpisahkan dari jalan yang membebaskan.

Pendidikan agama sesungguhnya sangat strategis jika anak didik didekatkan dengan dunia alam semesta. Karena sesungguhnya ajaran Islam yang dibawa oleh pesan-pesan alQur'an dan Hadis sarat dengan nilai-nilai yang memerintahkan manusia untuk berpikir menggunakan akal pikirnya untuk melakukan perenungan tentang alam semesta. Maka, sesungguhnya sangat ironi jika pembelajaran agama yang selama ini diajarkan di sekolah-sekolah hanya berhenti di antara temboktembok kelas yang membisu. Pembelajaran agama seyogianya tidak hanya menjadi menara gading yang seolah-olah tidak bisa disentuh oleh alam nyata, bahkan jauh dari dunia riil anak-anak. Karena sesungguhnya hal itu menyalahi kodrat kemanusiaan anak didik yang memang berada di alam nyata, tidak sedang mengembara dalam alam imaji yang sarat dengan teori-teori semata.

Alam bagi masyarakat primitif sebagaimana digambarkan Van Peursen memiliki daya magis yang dipenuhi dengan kekuatan-kekuatan gaib, diliputi rahasia dan sangat interesan. Jadi, inti sikap hidup mitis ialah bahwa kehidupan ini ada, ajaib dan berkuasa, penuh daya kekuatan. ${ }^{14}$

Sedangkan manusia modern memaknai alam tidak lagi hanya sebatas memiliki kekuatan magis dan bersifat gaib, tapi lebih kepada fungsi dan selalu menunjukkan kepada pengaruh terhadap sesuatu yang lain. Dan ini yang disebut oleh Van Peursen sebagai pemikiran fungsionalis. Apa yang disebut fungsional tidak berdiri sendiri, tetapi justru dalam suatu hubungan tertentu memperoleh arti dan maknanya. Dengan demikian, pemikiran fungsional menyangkut hubungan, pertautan, dan relasi. ${ }^{15}$

Dengan berpijak pada pemikiran Van Peursen tersebut, maka sesungguhnya saat ini untuk manusia modern sudah seharusnya terjadi pergeseran paradigma dari yang mitis menuju fungsionalis.

${ }^{14}$ Van Peursen, Strategi Kebudayaan, (Yogyakarta: Kanisius, 1988), hlm. 41-42.

${ }^{15}$ Peursen, Strategi Kebudayaan, hlm. 85. 
Alam tidak lagi menjadi sebuah fenomena yang menakutkan, penuh mistis dan gaib, sehingga dunia anak didik dijauhkan dari alam. Melainkan pendidikan Islam justru akan berubah jika mampu mendekatkan paradigma fungsionalis pada diri anak didik. Alam justru mempunyai fungsi yang sangat luar biasa terhadap dunia pembelajaran anak didik. Alam juga memberikan pengaruh yang luar biasa bagi pengembangan sains dan ilmu pengetahuan. Dengan demikian, pembelajaran agama berbasis sekolah alam sesungguhnya akan menghasilkan pengetahuan yang luar biasa jika mampu menjadikan paradigma fungsionalis sebagai paradigma pembelajaran yang mengarah kepada inovasi dan kreativitas belajar anak didik.

\section{F. Penutup}

Dalam konsep pendidikan sekolah alam, terdapat 3 fungsi, yakni: alam sebagai ruang belajar, alam sebagai media dan bahan mengajar, alam sebagai objek pembelajaran. Pendidikan Islam berbasis sekolah alam sesungguhnya mampu menjadi terobosan baru mencari format pendidikan Islam yang lebih humanis. Dengan pendidikan Islam berbasis sekolah alam diharapkan akan terjadi perubahan dalam semua dimensi pendidikan yang selama ini justru melanggengkan dehumanisasi. Dalam proses pembelajaran agama sangat dibutuhkan nuansa dialogis-harmonis. Karena persoalan pembelajaran agama tidak semata bersifat indoktrinasi nilai-nilai yang dianggap sudah mapan dan tidak perlu dikritisi dan direinterpretasi. Akan tetapi pembelajaran agama sesungguhnya sangat dinamis dan progresif.

Untuk mewujudkan pendidikan Islam yang humanis harus dimulai dari guru yang humanis pula. Seorang guru yang humanis sangat menghindarkan adanya penekanan pada siswa. Seorang peserta didik diterima apa adanya, dengan kelebihan dan kekurangannya sehingga tidak ada yang merasa tertekan, baik pihak siswa maupun guru, psikis maupun fisiknya. Seorang guru humanis tidak pernah menginginkan anak didiknya hanya sekedar menjadi peniru dari model yang ditampilkan gurunya. Implikasi aliran humanisme dalam pendidikan adalah keniscayaan pengembangan potensi diri manusia sebagai anak didik. Alam manusia modern sudah seharusnya terjadi pergeseran paradigma dari yang mitis menuju fungsional sehingga akan menjadikan 
proses pembelajaran agama berbasis sekolah alam akan menjadi lebih bermakna dalam kehidupan anak didik.

\section{Kepustakaan}

Freire, Paulo, Politik Pendidikan: Kebudayaan, Kekuasaan dan Pembebasan, terj. Agung Prihantoro dan Fuad Arif Fudiyartanto, (Yogyakarta: Pustaka Pelajar \& READ, 2002). http://sekolah alam/keuntungan anak belajar di sekolah alam usia sekolah parenting.co.id.htm, diunduh 7 Desember 2014.

http://elemen-elemen kritis dalam konsep pendidikan paulo freire.htm, diunduh 7 desember 2014.

Mas'ud, Abdurrahman, Menggagas Format Pendidikan

Nondikotomik Humanisme Religius sebagai Paradigma Pendidikan Islam, (Yogyakarta: Gama Media, 2002).

Mulkhan, Abdul Munir, Nalar Spiritual Pendidikan, (Yogyakarta: PT. Tiara Wacana, 2002).

Nur Chayati, "Menelusuri Akar Bungkamnya Daya Kritis", Edukasi, (vol. II, no. 1/Januari 2004).

Peursen, Van, Strategi Kebudayaan, (Yogyakarta: Kanisius, 1988).

Smith, William A., Conscientizacou Tujuan Pendidikan Paulo Freire, terj. Agung Prihantoro, (Yogyakarta: Pustaka Pelajar, 2001).

Steenbrink, Kareel A., Pesantren, Madrasah, Sekolah, (Jakarta: LP3ES, 1986).

Tuhuleley, Said, (ed), Masa Depan Kemanusiaan, (Yogyakarta: Jendela, 2003).

Yamin, Moh., Menggugat Pendidikan Indonesia Belajar dari Paulo Freire dan Ki Hajar Dewantara, (Yogjakarta: Ar-Ruzz Media, 2009).

Zuchdi, Darmiyati, Humanisasi Pendidikan, (Jakarta: Bumi Aksara, 2008). 
